\title{
Shear Behavior of Concrete Beams Strengthened with CFRP Grid and PCM Shotcrete
}

\author{
Andi Arwin Amiruddin ${ }^{\mathrm{a} *}$

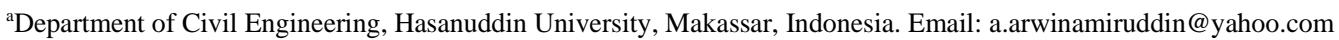

\begin{abstract}
The results of an experimental and analytical study of the shear behavior of damaged or under-strength concrete beams strengthened with carbon fiber reinforced plastics (CFRP) grid and polymer cement mortar (PCM) shotcrete describes in this paper. The aim of this study is to evaluate shear performances of reinforced concrete beams retrofitted by using PCM shotcrete and CFRP grid. Four concrete beams reinforced internally with steel and externally with both PCM and CFRP grid (longitudinal direction used CR-10 and transversal direction used CR-6) applied to the specimens were tested under three-point bending. The shear failure is initiated by a major diagonal crack within the beam shear span. This diagonal crack extended horizontally at the level of the CFRP grid. Results show that PCM shotcrete with CFRP grid is very effective for shear strengthening. Increases in strength of $140 \%$ for PGB over the RCB as control, unretrofitted beams were noted.
\end{abstract}

Keywords: Carbon Fiber Reinforced Plastics (CFRP) grid; Polymer Cement Mortar (PCM) shotcrete; shear behavior; strengthened

\section{Introduction}

Retrofit approaches may employ any innovative or economical scheme to prevent a RC bridge pier from collapsing during a design earthquake. One of the retrofit approaches is the strengthening of critical components [1, 2]. Strengthening is a widely used to retrofit approach that calls for increasing the force or moment capacity of selected components along the lateral load path to prevent premature or brittle failure [3]. An ideal strengthening should not alter the stiffness. However, since this is usually difficult to achieve, a re-evaluation of the seismic forces for the retrofitted RC bridge pier is required [4, 5]. Nowadays, retrofit materials with fiber reinforced polymer (FRP) and polymer cement mortar (PCM) are being used for a large variety of applications such as, bridge pier, bridge slab overlays, aqueduct tunnel, and box culvert. The prediction of mechanical properties of those materials plays an important role in the selection of materials and the design of each application case. Fiber reinforced plastics (FRP) have been considered as a substitute for conventional steel reinforcement owing primarily to their high corrosion resistance [6]. In addition, high strength, lightweight and non-conductivity of FRP composites have attracted the attention of researchers, as well as the industry. Although FRP reinforcements are more expensive than conventional steel reinforcements, the

\footnotetext{
${ }^{\star}$ Corresponding author. Tel.: +62-821-9042-3578

Jl. Poros Malino, Borongloe, Bontomarannu, Kabupaten Gowa, Sulawesi Selatan 92171
}

potential savings in maintenance costs make FRP reinforcements a viable alternative. Moreover, polymer cement mortar (PCM) consists of polymer cement mortar with polymer modified added is used to wrapping around $\mathrm{RC}$ bridge piers. In Japan, industrial companies produce many product types of PCM. For example, SABU 15 and SABU 15D, RIS SHOT, RFSP and ARMOR, respectively. On the other hand, there are some methods usually used to compact PCM as retrofit material in the fieldwork such as plasterer method and shotcrete method. In this research, PCM with high strength is used to retrofit RC beams by the shotcrete method. Strengthening reinforced concrete (RC) beams with fiber-reinforced polymer (FRP) composites is becoming an attractive for the construction industry [7, 8]. Commercially available FRP reinforcements are made of inorganic or organic fibers, such as glass (GFRP), carbon (CFRP) and aramid (AFRP), embedded in thermosetting resin matrix (polyesters, vinyl esters, and epoxies) and inorganic fillers. Unidirectional CFRP grid materials used in concrete reinforcement applications are linear elastic up to failure, and CFRP grid does not exhibit the yielding behavior that is typically displayed by conventional reinforcing steel $[9,10]$. CFRP grid (high strength and high elasticity carbon fiber) materials generally have much higher strength than the yield strength of steel, although CFRP grid does not exhibit yield. Nowadays in Japan, CFRP grid and polymer cement mortar (PCM) shotcrete had been developed to retrofitting of RC structures such as to increase the shear capacity of RC beams [11, 12]. The contribution of the 
CFRP grid (CR-6 and CR-10, high strength) transverse strengthening to the shear capacity on retrofit of $\mathrm{RC}$ beams is studied in this research. PCM (high strength and low elasticity) generally contains cement, fine aggregates, lightweight aggregate and polymer. PCM has the excellent bond strength, cohesiveness, improved resistance to freezing and thawing, reduced permeability, increased electrical resistivity and improved resistance to chemical attack [13].

\section{Experimental Program}

\subsection{Test specimens and FRP strengthening system}

The test specimens consisted of four RC beams classified into two types according to FRP strengthening system is shown in Fig.1. Two beams were tested without strengthening (RCB) and served as a control specimen for comparison purposes to evaluate the improvement in shear strength provided by externally bonded FRP reinforcements and PCM high strength shotcrete method. Two beams (RGB) were strengthened with FRP systems using Carbon Fiber-Reinforced Plastics (CFRP) grid rebars. A summary of these beams is given in Table 1 .

\subsection{Material properties}

A design and experiment of material properties values of the concrete and PCM are given in Table 2. Moreover, Table 3 shows kinds of steel reinforcement were used in the experiment. The CFRP grid properties as reported by the manufacturers with linear stress strain behavior up to failure in longitudinal and transversal directions are shown in Table 4.

\subsection{Test set-up}

All beams were loaded in three-point bending that the subjected to static load is shown in Fig. 2. The beams were

Table 1. Summary of specimen types

\begin{tabular}{ccc}
\hline Type & PCM & CFRP Grid \\
\hline RCB & - & - \\
\hline PGB & High strength & High strength \\
\hline
\end{tabular}

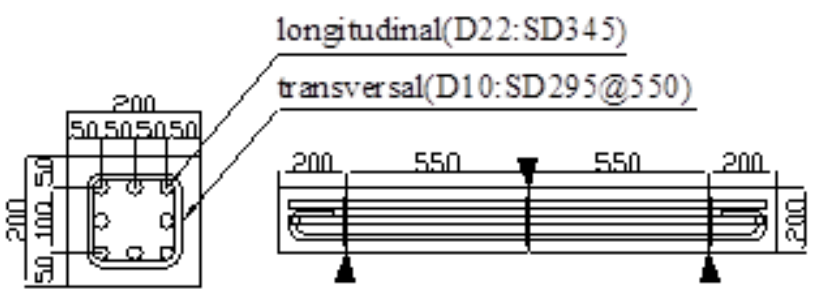

(a) $\mathrm{RCB}$

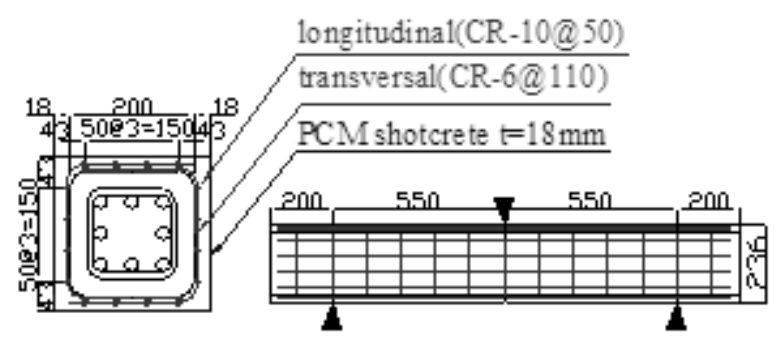

(b) PGB instrumented with a displacement meter at the mid-span and both of loading point to monitor displacement, as well as strain gauges bonded on concrete, PCM, and CFRP grid surface to measure the strain values. A $500 \mathrm{kN}$ load cell was used to measure the applied load.
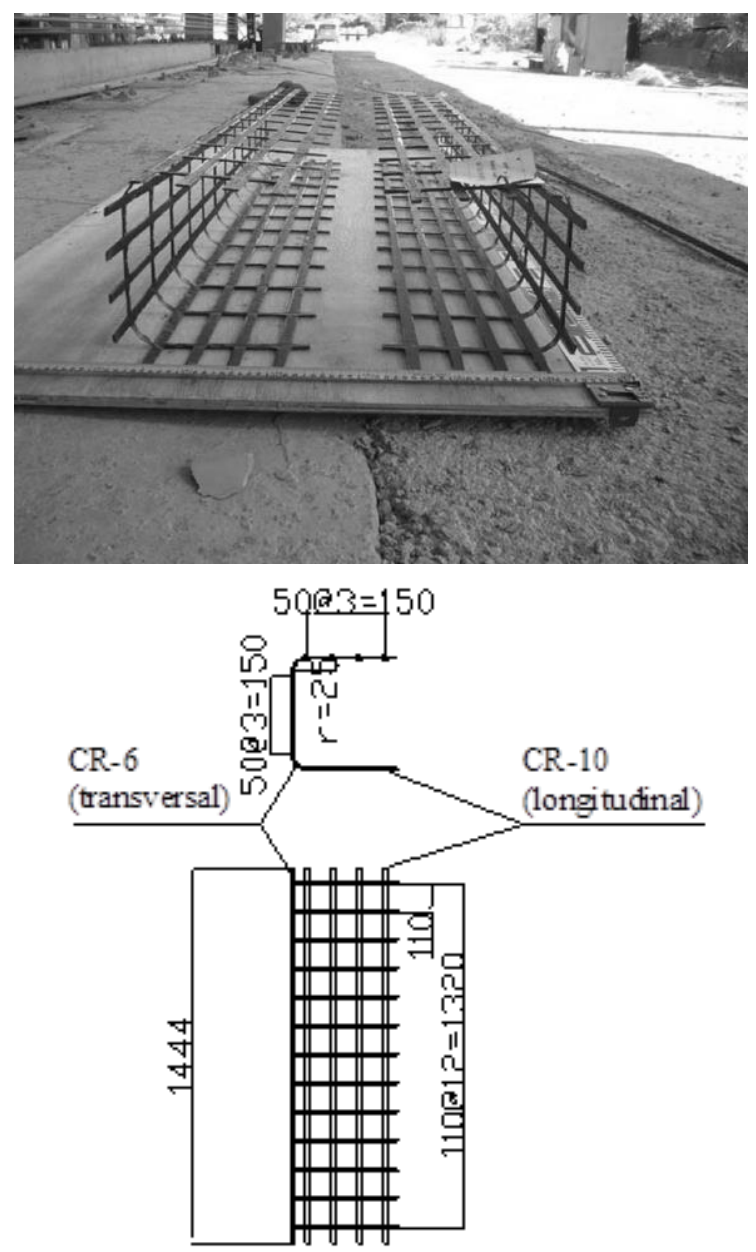

Figure 1. Test specimens and FRP grid strengthening system

Table 2. Material properties of concrete and PCM

\begin{tabular}{ccccc}
\hline \multirow{2}{*}{ CF grid } & Direction & $A_{c f}$ & $f_{t}$ & $E_{c f}$ \\
\cline { 3 - 3 } & & $\left(\mathrm{mm}^{2}\right)$ & $\left(\mathrm{N} / \mathrm{mm}^{2}\right)$ & $\left(\mathrm{N} / \mathrm{mm}^{2}\right)$ \\
\hline \multirow{2}{*}{ CR-10 } & Longitudinal & 39.2 & & 1400 \\
\hline CR-6 & Transversal & 17.5 & & $1.0 \times 10^{5}$ \\
\hline
\end{tabular}

Table 3. Material properties of steel reinforcement

\begin{tabular}{|c|c|c|c|c|c|c|}
\hline \multirow{2}{*}{ Type } & \multirow{2}{*}{ Item } & $\begin{array}{c}\text { First } \\
\text { Crack } \\
\end{array}$ & $\begin{array}{l}\text { First } \\
\text { Yield } \\
\end{array}$ & Ultimate & $\begin{array}{c}\text { Shear } \\
\text { Strength }\end{array}$ & $\begin{array}{c}\text { Comparison } \\
\text { of } P_{s}\end{array}$ \\
\hline & & \multicolumn{3}{|c|}{$P_{c r}(\mathrm{kN}) P_{y 0}(\mathrm{kN}) P_{u}(\mathrm{kN})$} & $\begin{array}{c}P_{s} \\
(\mathrm{kN})\end{array}$ & $\begin{array}{c}\text { Experiment } \\
\text { Analysis }\end{array}$ \\
\hline \multirow{2}{*}{$\mathrm{RCB}$} & Experiment & 15.1 & - & - & 147 & \multirow{2}{*}{1.3} \\
\hline & Analysis & 19.3 & 211 & 216 & 112 & \\
\hline \multirow{2}{*}{ PGB } & Experiment & t 29.0 & - & - & 352 & \multirow{2}{*}{0.9} \\
\hline & Analysis & 24.7 & 535 & 438 & 376 & \\
\hline
\end{tabular}


Table 4. Material properties of CFRP grid

\begin{tabular}{cccccc}
\hline \multirow{2}{*}{ Type } & Materials & \begin{tabular}{c}
$f_{c}$ \\
\cline { 3 - 6 }
\end{tabular} & $\begin{array}{c}E_{c} \\
\left(\mathrm{~N} / \mathrm{mm}^{2}\right)\end{array}$ & $\begin{array}{c}f_{c} \\
\left(\mathrm{~N} / \mathrm{mm}^{2}\right)\end{array}$ & $\begin{array}{c}E_{c} \\
\left(\mathrm{~N} / \mathrm{mm}^{2}\right)\end{array}$ \\
\hline RCB & Concrete & 30.0 & $2.80 \times 10^{4}$ & 35.0 & $3.06 \times 10^{4}$ \\
\hline PGB & $\begin{array}{c}\text { PCM-high } \\
\text { strength }\end{array}$ & 68.2 & $2.70 \times 10^{4}$ & 69.5 & $2.61 \times 10^{4}$ \\
\hline
\end{tabular}

Table 5. Comparison of experiment and analysis values

\begin{tabular}{cccccc}
\hline Diameter & Standard & Direction & $\begin{array}{c}f_{y} \\
\left(\mathrm{~N} / \mathrm{mm}^{2}\right)\end{array}$ & $\begin{array}{c}f_{t} \\
\left(\mathrm{~N} / \mathrm{mm}^{2}\right)\end{array}$ & $\begin{array}{c}E_{s} \\
\left(\mathrm{~N} / \mathrm{mm}^{2}\right)\end{array}$ \\
\cline { 1 - 5 } D22 & SD345 & Longitudinal & 395 & 582 & $2.0 \times 10^{5}$ \\
\cline { 1 - 5 } D10 & SD345 & Transversal & 323 & 455 & \\
\hline
\end{tabular}

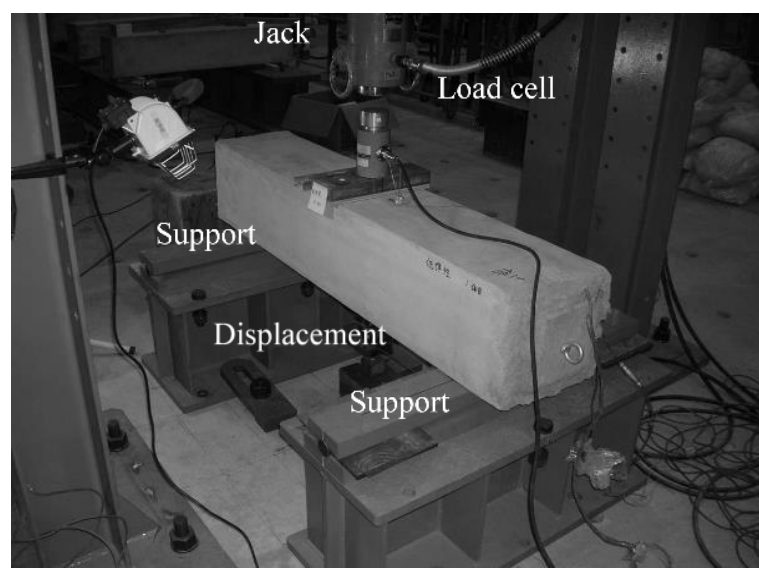

Figure 2. Specimen under testing and loading system

\section{Results and Discussions}

\subsection{Comparison of experiment and analysis values of Ps}

The design of load is divided into four parts, load at first crack $\left(\mathrm{P}_{\mathrm{cr}}\right)$, first yield at steel reinforcement in tension area $\left(\mathrm{P}_{\mathrm{y} 0}\right)$ so that steel bars was separated with concrete, ultimate strength $\left(\mathrm{P}_{\mathrm{u}}\right)$, and shear strength $\left(\mathrm{P}_{\mathrm{s}}\right)$. In particular for $\mathrm{P}_{\mathrm{s}}$, the analysis was carried out based on Japan Road Association (JRA) Bridge Part V method. In design, the shear failure was proposed on $\mathrm{P}_{\mathrm{y} 0} / \mathrm{P}_{\mathrm{s}}>1$.5. In experiment result, it was obtained that for all of specimen types had propagation of cracks showed shear failure behavior. Especially for PGB type, slip between CFRP grid and PCM was occurred so that obtained CFRP grid was not broken but separate with PCM and experiment value become less than design value. The comparison of experiment and analysis value is given in Table 5 and Fig. 3 , respectively.

\subsection{Load-deflection relationship}

The load deflection as showed in Fig. 4 plot for beam PGB along with that of the shear control beam, RCB. The control beam failed in shear and also for PGB type. PGB type had shear strength more than RCB type and increases in shear strength of $140 \%$ for PGB over the RCB、 unretrofitted beams.

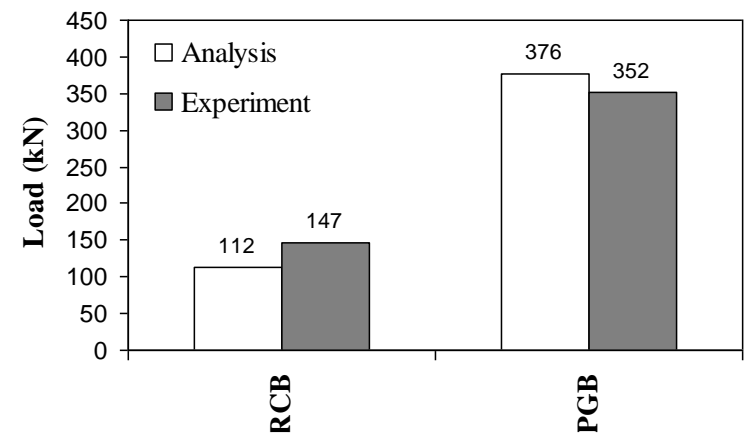

Figure 3. Shear strength values

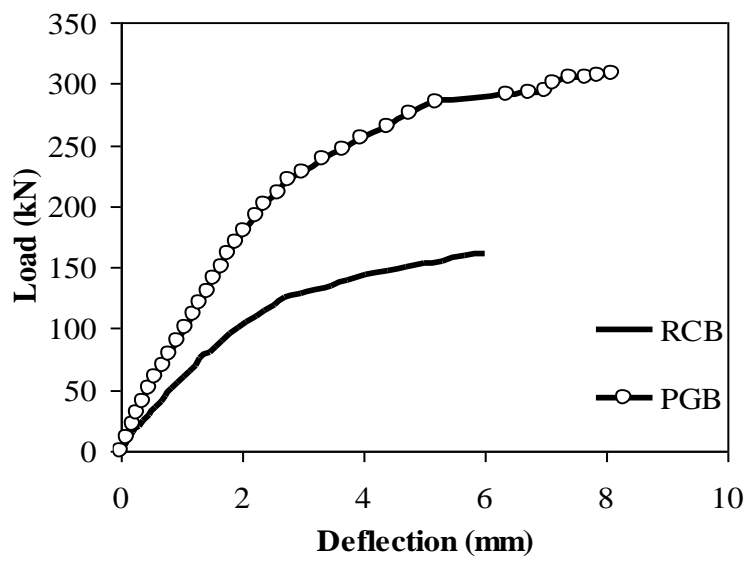

Figure 4. Load deflection relationship

\subsection{Load - strain relationship}

Figure 5 shows relationship of shear load with compressive strain of concrete/PCM and tensile strain of steel bars/CFRP grid. Tensile strain of steel bars of RCB was achieved up to about $1,300 \mu$ at the maximum of shear load. On the other hand, tensile strain of PGB type was achieved up to $4,500 \mu$ but less than $14,000 \mu$ as a design value for tensile strain of CFRP grid. Therefore, all of beams the specimens had shear failure modes. Figure 6 shows the crack pattern and failure mode of the beam under test.

\section{Conclusions}

In three-point bending test results, RCB type as control beam or un-retrofit type failed by shear. However, the retrofit specimens (PGB) also were failed at shear and these conditions parallel with design concept. PGB type was failed by separation with epoxy adhesive from PCM. CFRP grid had not enough adhesive strength to prevent relative slip to PCM. Based on experiment results, the retrofit of RC beams (PGB) by industrial method (SRS) have revealed that shear strength increase $140 \%$ as significantly to control beam. 


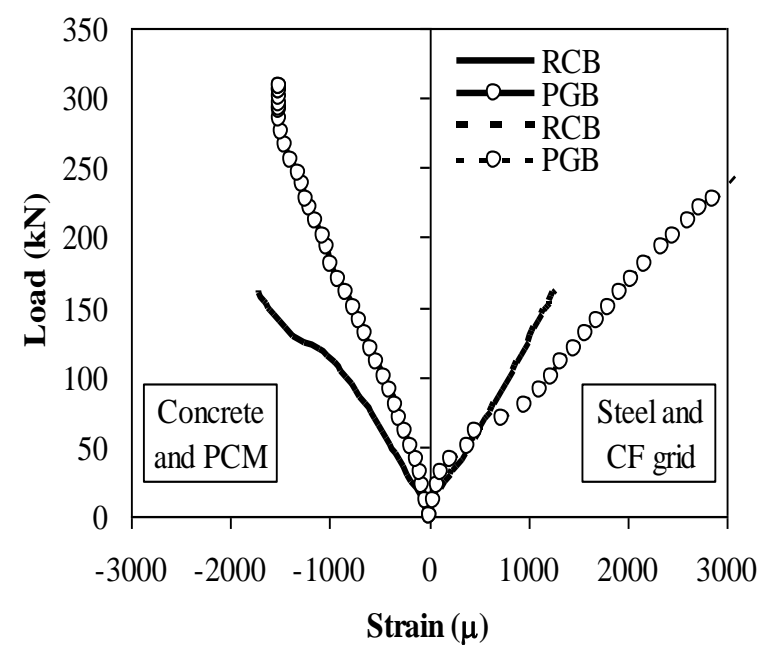

Figure 5. Load strain relationship
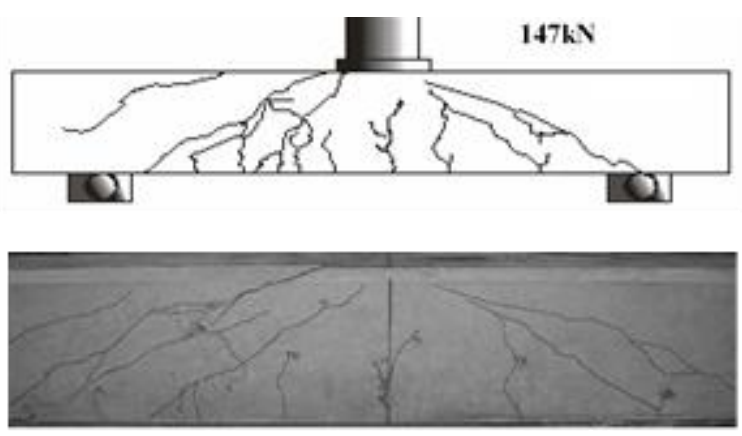

(a) RCB
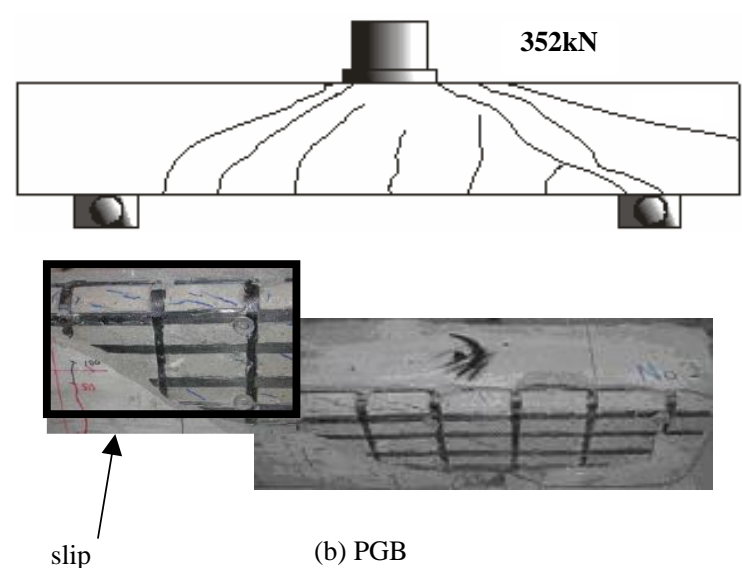

Figure 6. Crack pattern and failure mode of beam under test

\section{Acknowledgments}

I kindly would like to express my sincere gratitude to Prof. Shinichi Hino for his valuable help. The authors also wish to express the gratitude to Association of PCM shotcrete method for RC structures in Japan and FRP Grid Engineering Association for the finance support of this research as well as to the Laboratory of the Bridge and structural aesthetic design of the Kyushu University, Japan.

\section{References}

[1] Kawashima, K., "Seismic Design and Retrofit of Bridges", 12 WCEE 2000, pp.16, 2000.

[2] Theodorakopoulos, D. D., Swamy, R. N., "A Design for Punching Shear of FRP-Reinforced Slab-Column Connections", Cement and Concrete Composites Journal, Vol.30, Elsevier Ltd, pp.544-555, 2007

[3] Priestley, M. J. N., Seible, F., Calvi, G. M., "Seismic Design and Retrofit of Bridges", A Wiley-Interscience Publication, John Wiley \& Sons, Inc., New York, United States of America, pp.308-310, 1996.

[4] Kitada, T., Yamaguchi, T., Matsumara, M., Okada, J., Ono, K., Ochi, N., "New Technology of Steel Bridges in Japan", Journal of Constructional Steel Research, Vol.58, Elsevier, pp.21-70, 2002.

[5] Kitada, T., Matsumura, M., Otoguro, Y., "Seismic Retrofitting Techniques Using an Energy Absorption Segment for Steel Bridge Piers", Journal of Engineering Structures, Vol.25, Elsevier, pp.621635, 2003.

[6] Chagnon, N., Massicotte, B., "Seismic Retrofitting of Rectangular Bridge Piers with CFRP”, ConMat'05 Third International Conference on Construction Material, Canada, pp.1-10, 2005.

[7] Fujikura, S., Bruneau, M., "Blast Resistance of Seismically Designed Bridge Piers", The 14th World Conference on Earthquake Engineering, Beijing, China, pp.12-16, 2008.

[8] Japan Road Association (JRA). (2003). Specification for Highway Bridge Part V, Seismic Design, Japan. (English Translation)

[9] Iemura, H., Takahashi, Y., Sogabe, N., "Development of Unbonded Bar Reinforced Concrete Structure", 13th World Conference on Earthquake Engineering, Vancouver, B.C., Canada, pp.1-15, 2004.

[10] Shima, H., Chou, L., Okamura, H., "Micro and Macro Models for Bond in Reinforced Concrete, Journal Faculty of Engineering, The University of Tokyo (B); XXXIX (2), pp.133-194, 1987.

[11] Liang, J.; Kimitaka, A.; Takanashi, Y. (2008). Shear Strengthening of RC Beam with CFRP grid and Sprayed Mortar, Japan Concrete Institute (JCI), Vol.30, No.2, Fukuoka, Japan, pp. 1609-1614. (English Translation)

[12] Saatci, S.; Vecchio, F. J. (2009). Effect of Shear Mechanism on Impact Behavior of Reinforced Concrete Beams, ACI Structural Journal, Vol.106, No.1, pp. 78-86.

[13] Kasakura, R.; Uji, K.; Liang, J.; Sato, K. (2007). Shear Resisting Mechanism of RC Beam Strengthened with CFRP grid and Sprayed Mortar, Japan Concrete Institute (JCI), Vol.29, No.2, Sendai, Japan, pp. 853-858. (English Translation) 